\title{
An Ethnographic Study of Conflict in Software Engineering Teams
}

\author{
John Karn \\ University of Sheffield, Sheffield, UK
}

J.Karn@sheffield.ac.uk

\begin{abstract}
This paper describes an ethnographic study of conflict in software engineering teams. The aim of the study was to uncover whether certain forms of conflict can be either constructive or destructive. Prior research has uncovered three dist inct forms of conflict: task, relationship, and process. This trichot omy was used to measure conflict in this study. Additionally, each conflict episode was recorded to identify if certain issues were more likely to result in either constructive or destructive conflict. The initial findings of this research indicate that some forms of conflict are destructive regardless of the context they occur in. It was also found that the levels of skill and experience of team members and the methodology being adhered to can also play a role.
\end{abstract}

Keywords: Conflict, ethnographic study, soft ware methodologies, soft ware engineering teams, project clients.

\section{Introduction}

This paper describes an ethnographic study that involved observing seven software engineering (SE) teams. The teams were observed for the duration of their projects with the goal of gaining an insight into the conflict episodes that took place. The aim of this work was to examine whether or not certain forms of conflict are constructive or destructive in a cooperat ive SE team context.

$\mathrm{SE}$ is a team based activity; success is to a large extent dependent on how well team members interact and cooperate with one another over the duration of a particular project. Several scholars have argued that the social factors of SE are just as, if not more important than, the technical side of things (Cohen \& Bailey, 1997; Curtis, 1991; Curtis et al., 1991; Neilsen, 1996). These arguments have led to the inclusion of group projects in many undergraduate and graduate level SE courses. The raison d'etre for giving these projects is to enable the students to gain experience in working as part of an SE team aiming to deliver a software solution. An aim is to encourage students to develop joint problem solving skills (Johnson, 1998).

Despite its obvious advantages, group work is not without its problems. A major issue to contend with during any group based activity is

Material published as part of this publication, either on-line or in print, is copyrighted by the Informing Science Institute. Permission to make digital or paper copy ofpart or all of these works for personal or classroomuse is granted without fee provided that the copies are not made or distributed for profit or commercial advantage AND that copies 1) bear this notice in full and 2) give the full citation on the first page. It is permissible to abstract these works so long as credit is given. To copy in all other cases orto republish or to post on a serveror to redistribute to lists requires specific permission and payment of a fee. Contact 0HPublisher@InformingScience.org to request redistribution permission. that of conflict. People are said to be in conflict when the actions of one person are interfering, obstructing, or in some other way making another's behavior less effective (T josvold, 1997).

Other researchers have looked at conflict specifically within SE teams (Curtis, Krasner, \& Iscoe, 1988; Curtis, Walz, \& Elam, 1993; Elam \& Walz, 1988; Sawyer, 2001). The findings of 
these studies highlight that conflict and its management is a critical aspect of team-based SE. One study concluded by saying that how people work together is a stronger predictor of performance than the individual skills and abilities ofteam members (Sawyer, 2001). Conflict resolution is another important aspect to consider as failure to effectively resolve conflict will lead to feelings of anger and bitterness and damage team efforts (Curtis et al., 1993). If there are communication and coordination problems within teams, this serves to raise levels of conflict (Curtis et al., 1988). Ideally SE environments should not be conflict-free but conflict-managed environments (Elam \& Walz, 1988). Conflict behavior was said to be a normal part of group interaction and was neither intrinsically good nor evil. Elam and Walz (1988) developed a descriptive conflict model (Table 1) which had four elements: time, people, content, and process.

Table 1. Elam and Walz' Descriptive Model of Con flict

\begin{tabular}{|l|l|}
\hline Time & Frequency of conflict, concurrency of conflict, pacing of conflict \\
\hline People & Who's in conflict? With whom? \\
\hline Content & What is the conflict about? \\
\hline Process & $\begin{array}{l}\text { To what extent are disagreements substantiated? At what level of } \\
\text { abstraction are they substantiated? }\end{array}$ \\
\hline
\end{tabular}

The research described in this paper aims to build on these earlier studies. In particular it aims to build on the qualitative work of Elam and Walz (1988) by extending their descriptive model of conflict and focusing on conflict over a longer time period. This study also focused on specific forms of conflict and whether or not some forms can be beneficial.

Therefore this work aims to examine the following research questions.

1) Are some forms of conflict more destructive than others in an SE team environment and;

2) Are certain issues more likely to lead to constructive or destructive conflict?

The remainder of the paper is laid out as follows: the next section describes the research environment; following on from this the conflict definitions used, then the methodological procedure, descriptions of the individual teams who were observed, an overview of the results, a discussion of the results and answers to research questions, the limit at ions and finally the paper is concluded and sugge stions are made for future work.

\section{The Research Environment and Subjects}

The context for this study is the Software Engineering Observatory at the University of Sheffield. This is a research facility that is run by the Department of Computer Science's Verification and Testing (VT) research group. One of the objectives of this observatory is to allow researchers to observe, question, and interview students taking part in industrial SE projects. The rationale behind the creation of the observat ory was to aid those working in the field of empirical soft ware engineering.

The Observatory is based on several projects that are undertaken by different cat egories of students. The Software Hut is a second year undergraduate project that runs for one semester, Genesys Solutions is an MSc project spanning the entire academic year, and the Maxi project is another MSc project which runs for an ent ire academic year. The teams are typically made up of 4-6 students. The development can involve any of a variety of technologies including web-based, da- 
tabase, desktop and mobile communications. Seven teams in were observed in total, 2 Software Hut, 2 Genesys, and 3 Maxi.

The research subjects were second year undergraduates, fourth year, or MSc students. The undergraduates tended to be home students, i.e. UK domiciled. Unless they were mature students retuming from industry they lacked any large scale SE project experience. The fourth years were almost all home students and had completed all of their prior higher education at the University of Sheffield. In addition they had already completed the Soft ware Hut project, thereby having gained invaluable experience. The MSc students were an interesting group. These students tended to be predominantly from overseas (mostly from Asian countries with particularly large contingents from India and China, and to a lesser extent the Arab world and Greece). These students had not completed any of their previous education at the University of Sheffield. In the main they lacked any experience of large scale SE projects, unless of course they were ret urning from industry, which was the case for a small number of these students. An additional point worth not ing is that even for those MSc students with experience, they had no experience with using the particular methodology extreme programming (XP) (Beck, 1999, 2000) as prescribed by the management of Genesys.

There was a further divide in terms of the MSc level projects. The Genesys project was aimed at students with a background in SE; as mentioned earlier the fourth years had already completed their previous education at the University of Sheffield. The MSc's who took Genesys had either completed an undergraduate SE or computer science degree. The Maxi project on the other hand was taken primarily by students who, in many cases, came from a non-SE background. Their backgrounds varied from those with social science degrees, such as sociology and philosophy, to those who were technical and held degrees in subjects such as mechanical or electronic engineering.

The teams in the Software Hut were self-formed, with the students often knowing each other before the project. Even though the teams were self-formed an additional member was added to both teams. In Genesys and Maxi all of the teams were formed by the managers. These teams were not randomly formed. One important criterion was that there was a mixture of home and overseas students. Secondly in Genesys the managers formed teams on the basis of skill sets. They did as much as possible to ensure that teams consisted of members with varied skill sets and levels of experience.

Additionally, the students were expected to adhere to the tenets of the particular methodology they were following over the course of the project. In the case of the Genesys teams this was XP (Beck, 1999, 2000), whilst the Maxi teams followed a more traditional Wat erfall methodology, which has been described in several standard SE texts (Pfleeger, 2001; Pressman, 2001; Sommerville, 2004). Software Hut teams were divided into XP (Beck, 2000) and Discovery (Simons, 1999).

There are import ant differences between agile methods like XP and traditional methods such as the Waterfall Methodology. One major difference between XP and Waterfall is that the former is very light on documentation. Documentation in XP consists mainly of "story-cards," which the team uses to outline planned feat ures of the system. The second major difference is that XP is not a linear, but an iterative methodology. There are no specific phases such as analysis, design, and testing which are found in traditional methodologies. Finally, there is no soft ware specification in XP. Test cases written before the code is developed are said to serve this purpose. There are other points to consider but further discussion of the differences between traditional and agile methods is outside the scope of this paper. Most of the MSc students and the second year undergraduates taking the Software Hut module had no prior XP experience. They came from traditional software 
engineering backgrounds. Therefore having to learn the tenets of a new methodology is another fact or to consider when discussing conflict in SE teams.

In terms of the development environment, Genesys being a commercial software house has its own premises. This includes both Windows and Linux machines, and meet ing rooms to be used for both team and client meetings. Students from other modules are not allowed to use the Genesys lab. All work that takes place on the premises must be Genesys related. There is usually an agreement between the different Genesys teams over who will work where in the lab; students then tend to stick to their positions throughout the academic year. Maxi and Software Hut students do not have their own premises. When they are working at the University of Sheffield they must make use of the main computer lab in the Dept of Computer Science. This lab is open to all students in the dept; this means it is not so easy to coordinate team-work, but by no means impossible. As there are no regulations in Maxi and Software Hut stating that students must do all of their work on departmental machines or in a certain office there tends to be more cases of students working at home and sometimes less coordination between team members.

\section{Conflict}

The traditional view of conflict is that it is a serious threat to teams both in terms of the relationship between members and on performance (Dyson, Godwin, \& Hazlewood, 1976). Methods have been derived to counter this perceived threat. Such methods include effectively designing teams at the out set of a project in an attempt to minimize the probability of conflict erupting (Pelled \& Adler, 1994), having a rigid authority hierarchy to maintain order, and effective leaders who should act decisively to end disputes (Baxter, 1982). This view has been challenged as some scholars have argued persuasively that when positive conflict is recognized, acknowledged, and managed in a proper manner, personal and organizat ional benefits can accrue (Amason, 1996; Darling \& Walker, 2001).

\section{Different Forms of Conflict}

The decision to use the task, process, relationship trichotomy was based primarily on the wealth of empirical support that exists in the conflict literature. It has been proven to be a reliable method for measuring conflict in teams in a wide variety of scenarios. Historically scholars have distinguished between conflict based on the substance of the task being performed and conflict based on interpersonal relations (Guetzkow \& Gyr, 1954; P inkley, 1990; Wall \& Nolan, 1986). Others have used the terms "cognitive" and "affective" conflict to denote task and relationship conflict (Amason, 1996; Amason \& Sapienza, 1997). In recent years the trichot omy has gained in popularity primarily due to the work of Jehn (1995; 1997), De Dreu and van Vianen (2001), and De Dreu and Weingart (2003). What follows is a description of each of these forms of conflict and how they have been found to affect the performance of teams:

\section{Task conflict}

Task conflict is an awareness of differences and viewpoints pertaining to specific team tasks. It involves differences in viewpoints, ideas, and opinions. Examples are conflicts about the distribution of resources, about procedures or guidelines, and about the interpretation of facts. This type of conflict is said to be void of the negative interpersonal emotions more commonly associated with relationship conflict (Giebels, Janssen, Van de Vliert, \& Nauta, 1999; Jehn, 1997; Jehn \& Chatman, 2000).

Several studies show that task conflict has been found to be positively related to the quality of ideas and innovation (West \& Anderson, 1996), the increase of constructive debate (Jehn, Northcraft, \& Neale, 1999), the affective acceptance of group decisions, and the prevention of group- 
think (T urner \& Pratkanis, 1994). Van de Vliert and De Dreu (1994) suggested that too little task conflict can lead to inactivity because a sense of urgency is lacking. On the negative side too much task conflict can interfere with consensus and hinder the implementation of ideas (Schweiger \& Sandberg, 1989). This is backed up by a meta-analysis which found that high levels of task conflict can be as destructive as relationship conflict (De Dreu \& Weingart, 2003). Additionally, excessive levels oftask conflict can lead to emotional exhaustion (Giebels \& Janssen, 2005).

It appears that either very low or very high levels of task conflict can be damaging to a teams performance, whilst moderate levels are seen to be beneficial. This implies that there could be an inverted U relationship between task conflict and performance.

\section{Process conflict}

Process conflict is the least examined of the three types of conflict. Process conflict pertains to issues of duty and resource delegation, such as who should do what or how much work one should get. When team members disagree about whose responsibility it is to complete a specific duty, they are experiencing process conflict (Jackson, Johnson, Peterson, \& Trochim, 2002; Jehn, 1995).

There is evidence to suggest that moderately high levels of process conflict at the beginning and towards the end of projects is beneficial (Jehn \& Mannix, 2001). It could be the case that early discussions regarding task allocation may assist group members in assigning the correct peopleto the correct task. However other research has shown that disagreements among team members about "how to do it" had a detrimental effect on decision making (Passos \& Caetano, 2005). Process conflict was found to be associated with lower team morale as well as decreased productivity (Jehn, 1992). One study found that high levels of process conflict have a dysfunctional effect on both team performance and member satisfaction (Jehn, 1997). The typical problems caused by process conflict include group members working at cross purposes, inconsistencies in task roles, and time management problems that can lead to failure to meet deadlines. Process conflict can also serve to misdirect focus to irrelevant discussions of member ability.

\section{Relationship conflict}

Relationship conflict is said to be particularly damaging due to its interpersonal emotional nature. This kind of conflict relates to personal issues such as dislike and differences over att it udes, norms and values, personality, and political beliefs. It is characterized by feelings such as annoyance, frustration, and irritation (De Dreu, 1997; De Dreu \& van Vianen, 2001; De Dreu \& Weingart, 2003; Giebels \& Janssen, 2005; Jehn, 1992).

Relationship conflict is said to reduce team effectiveness (Jehn, 1997). It refers to tension, animosity, and annoyance among members within a group. The evidence shows that relationship conflict is to be avoided and that it offers no advantage to teams (De Dreu \& van Vianen, 2001; Dijkstra, van Dierendonck, \& Evers, 2005; Jehn, 1995, 1997; Jehn \& Shah, 1997). If team members are upset and annoyed with each othertheir performance and productivity can suffer.

These forms of conflict can be either constructive or destructive. Constructive conflicts are related to solutions and discussing ideas (Desivilya, 1998; Deutsch, 1980; Rognes, 1998; T josvold, Hui, \& Law, 2001). A constructive conflict is characterized by cooperation and flexibility. The principal focus is ontrying to achieve a solution between struggling parties that is mutually satisfact ory to everyone. Destructive conflicts (De Dreu, van Dierendonck, \& De Best-Waldhober, 2005; Wilmot \& Hocker, 2001) on the other hand are more related to power struggles and personal antagonisms. Destructive conflicts are characterized by domination, escalation, retaliation, competitions, and inflexibility. 


\section{Methodological Procedure}

As mentioned above, the research subjects were second year undergraduates, fourth year, or MSc students. They were working on projects for external industrial clients across the entire academic year in the case of the Maxi and Genesys teams, or for one semester in the case of the Software Hut teams. The clients were either from other university departments or industry.

The teams generally had two meetings per week, which usually lasted around one hour. To this must be added two extra hours per week during which the teams were observed as they worked on the project. Therefore, Soft ware Hut teams were observed for forty eight hours over a semester, and Genesys and Maxiteams were observed for twice the number of hours over the ent ire academic year. These observations yielded rich descriptive rich qualitative data and provided important insights into the issue of conflict in SE teams.

\section{Ethnographic Methods}

Ethnographic research methods were originally founded by social anthropologists to aid them in their understanding of different cultures and environments (Mead, 1975). In order to gain an indepth understanding of the user culture (in this context SE teams), it was necessary to observe, and inquire about the research subjects' normal activities throughout their specific projects in an attempt to gain an empathic understanding of this particular social scene. One of the key strengths of this method is that it allows one to gain an 'inside' account of the lives of people under observation (Atkinson, 1990; Becker, 1993; Lofland \& Lofland, 1984).

Ethnography has been defined as "the process in which an investigator establishes a many sided and relatively long-term relationship with a human association in its natural setting, for the purposes of developing a scientific understanding of that association"(Lofland \& Lofland, 1984).

Some of the key positive aspects of ethnographic methods can be summarized as:

They are least likely to lead researchers to impose their own reality on the social world they seek to understand.

The process of understanding action is omitted from other forms of research, and how and why people change is not understood.

During interviews there may be language or cultural differences expressed - in this case, observers may record their own experiences in order to understand the cultural universe which people occupy (subjective experiences) and convey these observations to a wider audience (from field notes), within the context of explaining the data (theoretical framework).

\section{Observations and the Coding Scheme}

In order to gather data for this study, researchers took the role of non-participant observers and observed meet ings between members of SE teams. In addition to the observations, informal interviews were conducted with individual developers before and after meetings. The research was explained to all of the students and clients at the start of a particular project. The students were also reassured that the observations and informal interviews had no bearing on their final mark, and that there would be no instances of students being reported to project management. The teams were typically made up of 4-6 students. When the students agreed to take part, they were instructed to inform researchers of any meet ings that were to take place

During the meetings a researcher would sit in the corner of the room to take field notes and note the verbal interactions between team members before, during, and after conflict episodes. The field notes provided a detailed insight into the conflict behaviours of the different SE teams. The observations continued for the duration of the project. The next step was to classify which kind of 
issue a conflict was related to; this is shown in Table 2 . These categories were developed inductively whilst analyzing the raw dat a from the field notes using a Grounded Theory type approach.

Table 2. Issue Types

\begin{tabular}{|l|l|l|}
\hline Code & \multicolumn{1}{|c|}{ Issue Type } & \multicolumn{1}{c|}{ Example } \\
\hline PSI & Project Specific Issue & $\begin{array}{l}\text { Project plans, budgets, specific requirements } \\
\text { documents, demonstrat ing soft ware, allocating } \\
\text { tasks, implementing feat ures }\end{array}$ \\
\hline MSI & $\begin{array}{l}\text { Methodology Specific } \\
\text { Issue }\end{array}$ & $\begin{array}{l}\text { Pair programming, st ory-cards, test-first, analysis } \\
\text { and design documentation }\end{array}$ \\
\hline GSEI & $\begin{array}{l}\text { General Software Engi- } \\
\text { neering Issue }\end{array}$ & $\begin{array}{l}\text { Programming languages, design diagrams UML, } \\
\text { DFD, and testing techniques, connect ing web- } \\
\text { page's to a database, security issues }\end{array}$ \\
\hline THF & Team Human Factors & $\begin{array}{l}\text { Personal issues between team members, animos- } \\
\text { ity, working practices, differences in attitude and } \\
\text { outlook, arranging social events, personal issues } \\
\text { unrelated to the project }\end{array}$ \\
\hline C & Client & $\begin{array}{l}\text { Planning and arranging client meetings, clashes } \\
\text { with the client, unrealistic expectat ions, getting } \\
\text { documents signed off }\end{array}$ \\
\hline M & Manager & $\begin{array}{l}\text { Preparing for manager meet ings, presenting work } \\
\text { tothe manager, discussing problems with the } \\
\text { manager, react ing to advice/criticism from man- } \\
\text { ager }\end{array}$ \\
\hline
\end{tabular}

The observed projects ranged from a website promoting control instrumentation as a career option to setting up a database for teachers of modern languages in the Sheffield area. Contributions from each member were noted as was any interaction between them. Each team member was anonymised and a code was used i.e. A3 or D4 to refer to them throughout the project.

The following excerpt from the field notes gives an indication of how Table 2 was used:

$\mathrm{xx} / \mathrm{xx} / \mathrm{xx}-$ Date

B1 PSI: Good things to put on the website would be quizzes, games, animations and flash movies B4 PSI: Says there should be an online game based on terrorists attacking a water plant B3 PSI: Agrees with B1's proposal, feels site should be entertaining

B1 PSI: Announced he had finished the cockpit game

PSI B1-Forgotten files for cockpit game had to get them off housemate via MSN messenger 
Table 3: Se ve rity of Conflict

\begin{tabular}{|l|l|}
\hline Ordinal ID & \multicolumn{1}{|c|}{ Name } \\
\hline 1 & $\begin{array}{l}\text { Premise uncritically accepted with no int eraction bet ween team } \\
\text { members. }\end{array}$ \\
\hline 2 & Dealt with smoothly and harmoniously after brief discussion. \\
\hline 3 & Lengthy period of constructive debate discussing the virtues of an issue. \\
\hline 4 & Caused slight disruption by forcing people off relevant issues. \\
\hline 5 & $\begin{array}{l}\text { Lengthy period of destructive debate, meet ing disrupted a lot of time } \\
\text { wasted getting back on track. }\end{array}$ \\
\hline 6 & Caused complete disruption to the work ofthe team. \\
\hline
\end{tabular}

Table 3 was used to ascertain whether a conflict was constructive or destructive. Each conflict was classified under one of these ratings. This scale was constructed in the early stages of the research after some initial observations had taken place. Issues from a selection of the first set of meetings were classified according to this scale. The scale proved to be robust and durable and provided a way to quickly classify each conflict episode as constructive or destructive based on the interactions between team members.

The first three ratings signify that an agreement was reached or an issue was resolved either immediately, after a brief debate, or after an extended constructive debate. In sharp contrast the second group of ratings corresponds to varying degrees of disruption. They range from forcing people off relevant issues via sarcasm, pedantry, or anger, to screaming matches that left people trembling with anger. Issues which were rated as 1 were not used in this study as 1 signifies a lack of debate, hence no conflict. Therefore 2 and 3 were used to cat egorize constructive conflict and likewise 4, 5, 6 for destructive conflict.

\section{Inter-Rater Reliability}

This research relied on one making observations of student teams and classifying conflict issues under an ordinal rating. In order to test for intra-coder reliability a selection of the data was recoded on a later date. The classification was also tested for inter-rater reliability. Internal and external impacts of disruptions or lack of debate were not tested. Inter-rater reliability is a measure of homogeneity. With inter-rater reliability, two people rate a behavior, object, or phenomenon and determine the amount of agreement between them. To determine inter-rater reliability, one takes the number of agreements and divides them by the number of total observations.

Two $\mathrm{PhD}$ level researchers were enlisted to help with this stage For reasons of anonymity they will be referred to as Z1 and Z2; both have a solid understanding of research methods. Both researchers were briefed on the nature of the research and received a full explanation of how the ordinal ratings system worked and how to trace each conflict episode from its inception to completion. Z1 and Z2 were instructed to select 15 random conflict episodes from teams observed overthe duration of the project. They then classified each issue under one of the ordinal ratings. Their ratings were then compared with those of the original researcher. A respectable level of inter-rater reliability was achieved; there was an inter-rater reliability measure of 0.8 with Z1 and 0.73 with Z2. 


\section{Results}

This section will present a summary of the conflicts that took place in all of the observed teams. The form of the conflict (constructive or destructive) will be presented, along with the issue and conflict type. In some cases examples from the field notes will be used to illustrate specific points.

\section{Software Hut Team A}

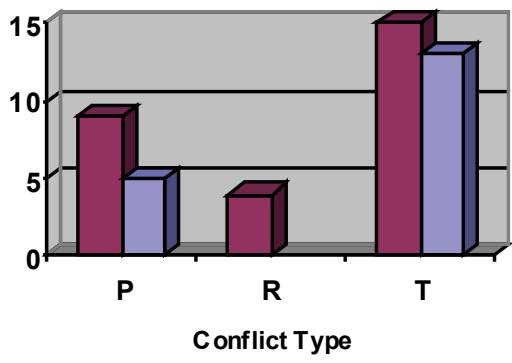

$\square$ Destructive

Constructive

Figure 1. Constructive and Destructive Conflict in Software Hut Team A

NOTE: Task, process, and relationship are abbreviated to $\mathrm{T}, \mathrm{P}$, and $\mathrm{R}$ on the charts

This project involved creating a web based pharmacovigilance database. Figure 1 shows that there was a high level of destructive conflict during this project. All of the developers had similar levels in terms of project experience, but a couple of students had more varied knowledge of programming languages. The majority of the conflict that took place in this team was of a destructive nature. In some cases it involved personal attacks, anger, and harsh sarcastic quips. The reasons for the large amount of destructive conflict are varied. One reason was the sarcasm, harsh comments, and hair splitting pedantry from one team member (A4). The member caused problems by offending other team members. This had the effect of either silencing the discussion or an attempt by the other members to freeze A4 out of the discussion. Direct confrontation between A4 and other members was rare. The following quotes taken from the field notes shed light on the nat ure of the relationship between A4 and the rest of his team:

"Does anyone have any suggestions about what to do with A4? Perhaps we need to issue an ultimatum, either he changes his attitude or we will report him to management." A1

"He (A4) is deliberately stifling discussions and offering no constructive comments; a lot of time is being wasted going over the same thing. That is when he even bothers to turn up." A3

Another reason was the fact that none of the team was experienced with XP; they were instructed to follow this methodology throughout the project. This caused confusion and led to many discussions about whether it was even possible to follow this methodology at all.

“We should stop being so worried about following XP practices. We are essentially following an unholy amalgamation of methodologies. " A2

"To be honest neither I, nor the client give a toss about whether or not we are following XP correctly. As long as we have something finished, by the end of the project." A5

A third reason for the conflict was that some team members (A2 in particular) had doubts about the very legitimacy of the project. These doubts centered on whether or not such a project was even valid for a Software Hut team. 
"Is this even a realistic project? It has too much scope." A2

Task conflict was the most common form of both constructive and destructive conflict in this team. Issues that were of a more personal as opposed to technical nat ure were most likely to end in destructive conflict. Examples of these issues include problems with A4 and lack of contact with other team members over Easter. Also working arrangements and arranging suitable meeting times was a problem as there was a long running issue between $\mathrm{A} 5$ and $\mathrm{A} 3$ and $\mathrm{A} 4$ in particular about thetiming of meetings.

"Too much time is being wasted by having meetings at 1 lam. An earlier meeting would make more use of the day." A5

"I am making a lot of effort to get here for 11 am. There is no way I can make it earlier; even now I am often late for meetings." A3

There were also problems relating to the working practices of this team. Certain team members preferred to work at home and found the whole experience of working in a team, often in a busy lab, to be quiet unsettling. This can be seen from the following quotes:

"This situation is far from ideal. There is too much noise in this lab. How can we get any work done?" A1

"I prefer to work at home, wather than here." A2

"I like to stay at home and shut myself off from the world." A4

PSI issues that resulted in destructive conflict taking place were usually derailed by sarcasm or pedantry from A4. This generally took the form of often barely audible sharp quips made in suggestion to ideas put forward or endless quibbling and forcing people to keep going over issues time and time again. The lack of experience with and negative att it ude to XP goes a long way to explaining the destructive MSI issues.

Due to the nat ure of the conflict in this team and the fact that it was initiated by and large by one person, the otherteam members eventually adopted effect ive conflict avoidance strategies. These included moving on when a point had been suitably discussed instead of going round in circles.

Eventually they started ignoring sarcastic comments. A decision was made not to assign any important work to A4 due to his unreliability. Despite the fact that they had to struggle with A4, the other members of the team proved to be hard working diligent individuals. There were many useful discussions between A1 and A2. Negative attitudes towards XP hindered effective adherence to this methodology, and the team never adjusted to pair programming. Despite these problems the team managed to produce a working system- but certain features were missing at the end of the project. It must be kept in mind that this particular project was said to be of a very complex and technical nature. Early on doubts were raised over whether it was suitable for second year undergraduates.

In light of the conflicts experienced during the project, how effective was this team? In terms of meeting the expectations of the client the team did produce a working system; on the negative side this did not have all of the requisite functionality as requested by the client. The team did not make any effort to incorporate any additional requirements or to increase the efficiency or elegance of their solution. As for the internal manager the team did not adhere to the specified software process XP. Although technically proficient they were also unconventional and chose to invent their own way of doing things. They even went so far to create their own scripting language. The manager appreciated the hard work from certain members of the team and awarded the team an above average mark. This is similar to the mark given by the client who recognized the complexity of the project. 
Table 4: Se verity and Impact of Conflict in Software Hut Team A

\begin{tabular}{|l|l|l|l|}
\hline Conflict Type & Se verity & Positive Impact & Negative Impact \\
\hline Task & Moderate & Generation of ideas & Too much sarcasm and pedantry \\
\hline Process & Moderate & $\begin{array}{l}\text { Challenged the status } \\
\text { quo }\end{array}$ & $\begin{array}{l}\text { A source of anger as working } \\
\text { practices were challenged }\end{array}$ \\
\hline Relationship & Low & N/A & $\begin{array}{l}\text { Led to an open breach with one } \\
\text { team member }\end{array}$ \\
\hline
\end{tabular}

\section{Software Hut Team B}

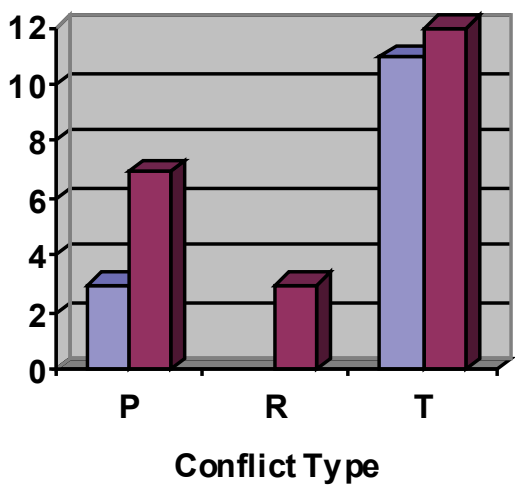

$\square$ Cons tructive
$\square$ Dest ructive

Figure 2. Con structive and Destructive Conflict in Software Hut Team B

This project involved creating a website promoting Control Instrumentation as a career option for school leavers. From Figure 2 we can see that there were many destructive conflicts and that they out numbered constructive conflicts. The team was instructed to follow the Discovery methodology. This didn't pose any problems as they were experienced with this methodology. They didn't have to adapt to new practices as the previous team did with XP. There were no constructive relationship conflicts, a majority of process conflicts were destructive, and there were a slightly greater number of destructive task conflicts. One team member (B1) had more SE experience than the others and wasn't afraid of voicing strong opinions; this didn't go down well with two otherteam members who did not like being told what to do. One member in particular (B3) did not like having his opinions challenged and was very short-tempered.

There were several reasons for the destructive conflict in this team. As discussed above there were three extraverted members (B1, B3, and B4) who were all boisterous and were not afraid to voice strong opinions. The second reason was the hostility toward the project client. The team had a strained relationship with the client from the start of the project, and it deteriorated as time passed. Finally, there were problems with one team member due to his lack of attendance in team meetings and for not doing work assigned to him.

The high number of negative process conflicts was due in part to the fact that this team did not have set roles for the project. The team had a very ad hoc way of allocating tasks; which stemmed back to the lack of clear team roles. This led to confusion over who should be doing what and when. There was also a problem with people overriding the authority of whoever was deemed to be in charge for a particular week. The following quotes illustrate some ofthe difficulties encountered:

"I suggest we allocate tasks by drawing names out of a hat." B3 
"That is sheer madness." B1 in response to B3

“Why don't we change roles on a daily basis?” $\mathrm{B} 4$

Loud angry exchanges particularly between B1 and B3 were a feature of meetings across a range of issues. On occasion there were very loud and angry screaming matches which dominated some meetings and made the atmosphere very unfriendly.

"You have wasted my time and your own time by researching something that isn't even needed for the project." B1 to B4 when the latter explained how he had been researching FPA

"You are trying to close down discussion and are forcing your will onto the team." B1 to B3

B5 was the source of much controversy throughout the project and on many occasions he was the primary subject of debate. The problems with B5 stemmed from him not turning up to team, manager, and client meet ings. He also gave what the other team members termed as unoriginal excuses such as "dentist appointment," "waiting to see landlord," and "careers meeting."

"I call for the expulsion of B5 from the team, due to him continually missing team meetings, and formaking up excuses for not doing work." B3

"I don't trust him [B5] at all." B3

For this team, issues that were of a more personal as opposed to technical nat ure were the most problematic. THF issues were most likely to end in a destructive conflict. The most interesting find is the large number of destructive conflicts which resulted from discussing client issues.

"I am not sure if it is a wise thing for us to be working on a project with a real industrial client." B1 at the start of the project

B3 was of the opinion that the team would have a hard job meeting the clients' requirements. In a later meeting B1 raised the idea of contacting other teams doing the same project and asking them if they had problems with the client.

"Perhaps we should contact the other teams working on this project. Maybe they are experiencing sim ilar problems." B1

"Should we ask the client if he is wasting our time? There is no point carrying on with the project if he isn't serious." B4

Personality clashes, disillusionment with the client, and the feeling that one team member (B5) was trying to avoid work all contributed toward the destructive conflicts which took place throughout this project. Despite the high levels of destructive conflict the team members were able to cast aside their differences when it really mattered. This was primarily because of the strong technical background of B1 and to a lesser extent B2 who rarely involved himself in interpersonal disputes but produced work of a consistently high standard. On completion of the project, the client was pleased with the soft ware that had been produced. The team was also praised by project management for producing a good solution.

As was mentioned above the client expressed great satisfaction with what had been produced by this team. They produced a solution which met the core requirements and included some of the optional ones, such as having interactive games. On top of this the website was easy to navigate and was flexible enough to be modified by the client should the need arise. The team also had no problems adhering to the SE process as defined by the manager. One reason for this could be that they had taken a module "Systems Analysis and Design" in the previous semester and the methodology taught was Discovery. Members of the team applied what they had learned to this spe- 
cific project and were praised for their effective use of the methodology. At least two members of this team were very strong technically. Despite high levels of conflict throughout they produced work of a consistently high standard. The manager was pleased with their efficient solution. The high levels of conflict may have impacted the performance of individual team members, but overall the manager and the client were happy with what had been produced.

Table 5: Se ve rity and Impact of Conflict in Software Hut Te am B

\begin{tabular}{|l|l|l|l|}
\hline Conflict Type & Se ve rity & Positive Im pact & Negative Impact \\
\hline Task & High & $\begin{array}{l}\text { High level of task con- } \\
\text { flict led to sound ideas } \\
\text { being generated }\end{array}$ & $\begin{array}{l}\text { A lot of anger and screaming } \\
\text { tended to poison the atmosphere }\end{array}$ \\
\hline Process & Moderate & $\begin{array}{l}\text { Forced people to carry } \\
\text { out specific tasks }\end{array}$ & $\begin{array}{l}\text { No set way of allocating tasks } \\
\text { led to a lot of anger }\end{array}$ \\
\hline Relationship & High & $\begin{array}{l}\text { Action taken against } \\
\text { problem member }\end{array}$ & $\begin{array}{l}\text { Personal insults and screaming } \\
\text { matches led to EGO battles } \\
\text { Too much focus on one member } \\
\text { (B5) }\end{array}$ \\
\hline
\end{tabular}

\section{Maxi Team A}

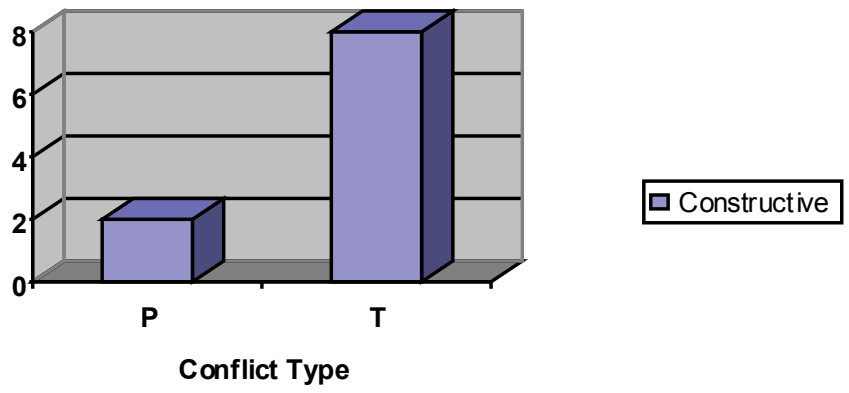

Figu re 3. Constructive and Destructive Conflict Maxi Team A

Figure 3 shows that conflict was all constructive in this team. What ever conflicts this team experienced were very focused and dealt only with technical and project issues as opposed to those of a more personal nature. This project involved creating an online resource for use by social science researchers. This team wasn't dominated by one or two individuals. Communication between the members was excellent throughout.

"C1 is very helpful with the documentation and C5 is our technical expert." $\mathrm{C} 1$

"Everyone is working well together. C5's input has been cnucial; he has helped to raise the technical knowledge of the whole team." $\mathrm{C} 1$

This team only experienced oneTHF conflict. Due to the nat ure of the team and the relationship between the different members many constructive conflicts took place. There were no personality clashes or problems with clients or methodologies. Despite the low levels of conflict the team produced a solid if not spectacular system, the client was moderately happy (certainly not over the moon), and stated improvements could and probably should be made. One reason for this was that there was only one real technical expert in the team, C5. Although it was never a case of C5 doing all of the work, he had to keep a close watch on some of his team mates as they struggled to get to grips with some technical concepts. This was especially the case when the team had moved 
beyond the analysis and design phases into development and testing. On the negative side there was no one to challenge C5's technical ideas. This also contributed to the fact that there were no destructive conflicts, as C5 was never challenged in a rigorous manner.

The manager noted that $\mathrm{C} 5$ was the driving force behind theteam; as a result of this the overall team performance was lower than it could have been. On several occasions the manager commented that one member of the team didn't seem to be contributing enough and rarely said anything during meetings. Whilst C5 was awarded a high mark for his efforts, other team members did not perform so well. One member was said to be so anonymous throughout that he was failed.

Table 6: Se ve rity and Impact of Con flict in Maxi Te am A

\begin{tabular}{|l|l|l|l|}
\hline Conflict Type & Se verity & Positive Impact & Negative Impact \\
\hline Task & Moderate & $\begin{array}{l}\text { An open environment } \\
\text { to exchange ideas }\end{array}$ & N/A \\
\hline Process & Low & $\begin{array}{l}\text { Roles were fairly } \\
\text { clearly defined }\end{array}$ & $\begin{array}{l}\text { People didn't get chance to work } \\
\text { on other parts of the system }\end{array}$ \\
\hline Relationship & Low & N/A & N/A \\
\hline
\end{tabular}

\section{Maxi Team B}

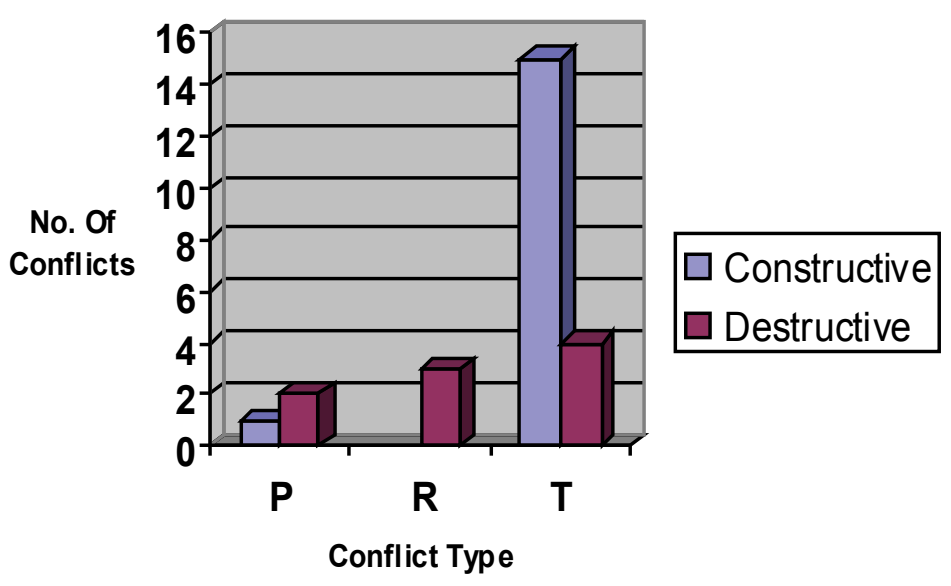

Figu re 4. Constructive and Destructive Conflict Maxi Team B

The students in this team worked to produce a document and version management system for a local software house. As Figure 4 illustrates members of this team engaged in many constructive task conflicts. The negative side of this is that many of these task conflicts were heavily driven by one team member (D1). This was to such an extent that other members made only token comments and failed to take control of many issues. This reliance on one member went a long way towards ensuring that the team paid the ultimate price. At the end of the project, they had unfinished documentation and a system that failed to meet the clients' requirements. This was because some of the core features had not been implemented. On the positive side it must be said that D1 was driven by a need to be precise and competent and expected the same high standards from team mates. This approach served the team well in the early stages when the team was concentrat ing on writ ing documentation. Indeed other team members were quick to accept the key role being played by $\mathrm{D} 1$ : 
"D1 is very good with ideas. He is proving to be a very useful member of the team." D4

"At times this team seems to be like a one man band. D1s contribution has been crucial." D3

Problems started to occur when the burden became too much for D1 during the coding stages and he felt other team members were not taking responsibility. Other team members were aware of serious problems during the implementation stage ofthe project; it was more of an effort during the production of analysis and design documentation. Lack of programming knowledge and experience seriously hampered the team later down the line. Early on in the project D2 uttered what turned out to be prophetic words:

"There are many problems and they will not simply go away. Team mem bers are expressing doubts and concerns about writing certain types of documentation and programming. These concerns are not being addressed by us as a team." D2

The team generally accepted that one member was responsible for the lion's share of the code. Not surprisingly the sheer pressure of this situation took its toll on D1's health. As the project ground on D1 started to complain about feeling weak and tired.

This team provided an archetypal example of what can happen when there is too much reliance on one member. This over reliance came about primarily due to a failure to organize work properly. As a result of this the destructive conflicts that did take place were all the more damaging.

Both the manager and the client were far from satisfied with the final product produced by this team. The soft ware did not even meet the minimal requirements and was not in a state that could be effectively used by the clients' organization without majortinkering. The manager said the team did not adhere to the guidelines he had laid down, nor did they adhere to the methodology. Relying heavily on one member led to a chaotic approach to work and the team often jumped from one phase to the next without the prerequisite foundations in place. The end result could be said to be disastrous. All team members, apart from D1, were failed; the result for the team as a whole was a failure.

Table 7: Se ve rity and Impact of Con flict in Maxi Te am B

\begin{tabular}{|l|l|l|l|}
\hline Conflict Type & Se ve rity & Positive Im pact & Negative Impact \\
\hline Task & Moderate & $\begin{array}{l}\text { Allowed one member } \\
\text { to fine tune his ideas }\end{array}$ & Heavily driven by 2A \\
\hline Process & Low & N/A & $\begin{array}{l}\text { Lack of process conflict led to } \\
\text { load overload for 2A }\end{array}$ \\
\hline Relationship & Low & N/A & N/A \\
\hline
\end{tabular}




\section{Maxi Team C}

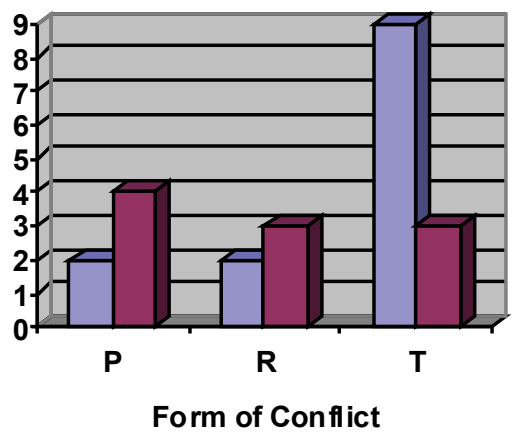

$\square$ Constructive
$\square$ Destructive

Figure 5. Constructive and Destructive Conflict Maxi Team C

From Figure 5 it is clearthat this team experienced a large amount of conflict. The team was dominated by two individuals (E4 and E5) forthe first half of the project, and then by one person (E2) for the remainder. The conflict that took place reflected this dichotomy. During the analysis and design phases E4 andE5 engaged in several constructive task conflicts but often failed to involve other members in the discussions. During the coding and testing phases, E2 worked hard, often alone, and rather than debating issues with people, he would summarize the work he had done over the previous week and then move on to a new task.

The main causes of destructive conflict in this team were the domination of E4 and E5 in the early stages and then the subsequent split of the team into three camps. E4 and E5 continued to work together, E2 worked alone, and E1 and E3 were largely left in the dark. Although it must be added that a vicious personal attack by E1 on E2 all but destroyed any chances of a successful partnership developing between E2 and E1/E3.

The lack of communication between E4 and E5 in the early stages was brought to the fore by the admission that the feasibility report that had been produced by the team was said to be disastrous. The manager advised the team to get together and go over it again.

"The feasibility report was said to be disastrous. We need to communicate with each other in a more coherent m anner." E5

During team discussions E4 and E5 occasionally remarked that they were doing most of the work and were in danger of being overloaded and that this was unfair.

"There are only two people, E4 and E5, working in this team. We have done almost all of the work so far. The documentation was basically done by us with little or no input from the others. " E4

This proved to be the root cause of the THF problems which plagued this team. Whilst other team members accepted this as a valid argument, E2 in particular refused to accept the full blame for the situation:

"I accept that we could have been more proactive at times. But you, E4 and E5, work together, often at home and som etimes speak in a foreign language. This alienates other team members." E2 
E4 and E5 were not interested in socializing with other team members, giving an impression of aloofness. This cameto a head when E4 issued a threat to walk out of the team due to dissatisfaction with the way things were progressing.

"I think I mightjust leave. This is supposed to be a team based project and the others are not getting involved, apart from E5." $\mathrm{E} 4$

The PSI problems affected areas such as budgets and stage plans, feasibility report, and design document, sothey were not minor concerns.

"Something has to be done about the other team members. E3 and I seem to be doing everything. They are not keeping in touch." E4

"E4 and E5 have separated themselves from the rest of the group. It is not that I don't want to do anything, they are notmaking efforts to involveme in the work." $\mathrm{E} 2$

A further problem forthis team was the fact that they had morethan one client. This caused disgruntlement amongst team members due to extended lines of communication and inconsistencies in the way the gatekeeper conveyed information to the main client.

"The clients are not synchronized and they make changes without consulting one another." E2

Despite facing a multitude of problems the team managed to complete the project and finished with full documentation and a working system. The fact that they had a working system was mainly due to E2's prodigious efforts in the final weeks of the project. E2 remarked that the project was a "real test of character and a learning experience".

Conflict did impact the performance of this team as it resulted in a pair doing most of the work for the first half of the project and an individual doing the same for the second half. The success of this team was due to hard work from these members and not because the whole team worked successfully togetherthroughout. The main client said that what had been produced did meet the minimum core requirements and was usable. However, there was scope for improvements in terms of the usability and efficiency of the system. The manager penalized the team for their lack of cohesion and because they had split off into sub-groups. One of the purposes of these projects is to encourage team working and to foster relevant skills. Therefore not working together in a cooperative manner was a major drawback as far as the manager was concerned. The team did not fail ent irely because they did manage to produce a working system, mainly due to an almost Herculean effort from E2 in the second half of the project. This effort was rightfully praised by the manager, but the negative side was E2s lack of interaction with his team-mates. The conflict that occurred did prevent this team from working together.

Table 8: Se ve rity and Impact of Con flict in Maxi Te am C

\begin{tabular}{|l|l|l|l|}
\hline Conflict Type & Severity & Positive Impact & Negative Impact \\
\hline Task & Moderate & $\begin{array}{l}\text { Lack of conflict } \\
\text { allowed team members } \\
\text { to focus on work }\end{array}$ & $\begin{array}{l}\text { Poor communication led to a } \\
\text { fragmented team }\end{array}$ \\
\hline Process & Low & N/A & $\begin{array}{l}\text { Team members complained they } \\
\text { didn't know what they were } \\
\text { supposed to be doing }\end{array}$ \\
\hline Relationship & Low & N/A & N/A \\
\hline
\end{tabular}




\section{Genesys Team 2}

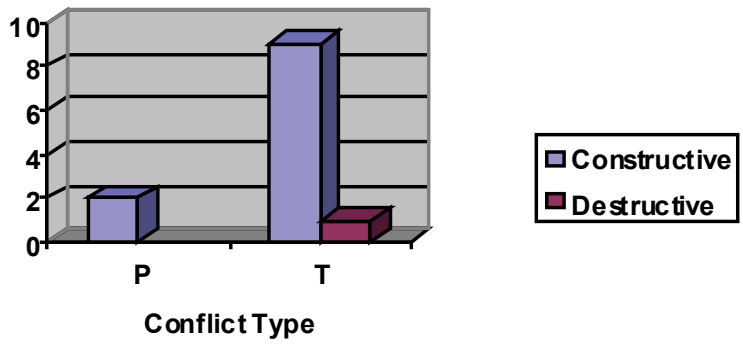

Figure 6. Con structive and Destru ctive Conflict in Genesys Team 2

Figure 6 shows that the conflict in this team was almost entirely constructive. This team was very strong technically. The key members had prior experience using XP, and they worked well over the entire academic as a cohesive unit. The members ostensibly cooperated and worked well together. The project was of a complex nature, and it involved creating an online examinations system for a university department. The client was also very demanding. There were no cases of people being forced to carry out tasks. A lot of discussion took place which allowed members to weigh the pros and cons of a particular option before deciding to go down a certain route.

The relationship between the different members of this team was very businesslike and small talk was generally avoided. This resulted in them having a strong commitment to the task at hand. This attitude was shared by all members, and a high level of cohesiveness was prominent from the beginning. As there were so few discussions of a personal nat ure the chances of a relationship conflict occurring were very slim. Indeed the conflict that did take place was made up entirely of a constructive task or process variety.

"This team has always welcomed any suggestions relevant to the task at hand. One of the key components of our success has been the open exchange of ideas and how we have kept the discussion focused on important issues." F1

In many ways this was a model project team in the sense that no member allowed any personal feelings to cloud discussions and all team members were actively involved in discussions. This team also demonstrated the beneficial aspects of conflict in team based projects. They focused on issues as opposed to personalities and offered constructive criticism of ideas.

The final outcome for this team was overwhelmingly positive. The project client expressed great satisfaction and appreciation, and the Genesys managers awarded the students with high marks. The lack of any interpersonal conflict meant that the team was focused purely on work matters, and on delivering a high quality software package.

Conflict affected the performance of this team in a positive manner. The task conflicts helped to generate ideas and provided team members with an opport unity to provide feedback. The managers were delighted with both the technical capabilities demonstrated throughout the project and how well the team members cooperated with each other. The more technically ast ute members were always careful to involve others in discussions and work; this led to a very impressive software solution. As mentioned above the client expressed appreciation for the obvious hard work which had gone int o the project. In addition the client stated that the soft ware had met his core requirements. Moreover the team had gone beyond that and produced a system that was superior in terms of usability, efficiency and maintainability. One or two members of the team lacked the technical expertise of their colleagues- this was not a problem as efforts were made to teach peo- 
ple the required skills. The more technically advanced members learned how to work in a mixed ability team and to still be successful. All team members learned a great deal about adhering to the XP methodology. This project was an overwhelmingly positive experience for all involved.

Table 9: Seve rity and Impact of Con flict in Genesys Team 2

\begin{tabular}{|l|l|l|l|}
\hline Conflict Type & Se ve rity & Positive Impact & Negative Impact \\
\hline Task & Moderate & $\begin{array}{l}\text { Focused conflict on } \\
\text { technical issues led to } \\
\text { successful project out- } \\
\text { come }\end{array}$ & N/A \\
\hline Process & Low & $\begin{array}{l}\text { Team members could } \\
\text { ask for and change } \\
\text { roles or for help from } \\
\text { others }\end{array}$ & N/A \\
\hline Relationship & Low & N/A & N/A \\
\hline
\end{tabular}

\section{Genesys Team 4}

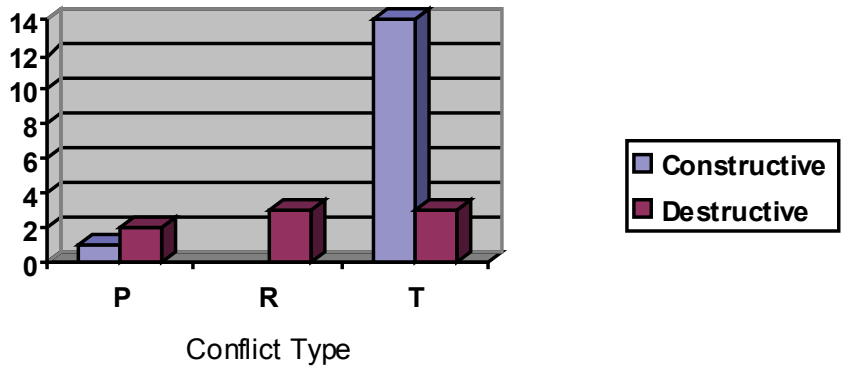

\section{Figure 7. Con structive and Destructive Conflict in Genesys Team 4}

This team was very diverse in its makeup, both in demographic terms and in skills and experience. Figure 7 shows there were many task conflicts. The project itself was also difficult and of a technically complex nature. Added to this was a strained relationship with the client, which went from bad to worse. The strained relationship with the client was one reason for the destructive conflict which took place. The second reason could be described as a personality clash and a clash of different working cultures. The team was supposed to be adhering to XP, yet what happened in practice was quiet different. It was particularly difficult for the developers to understand the role of documentation in an XP project. At times both they and the client felt that the lightweight documentation simply wasn't sufficient to capture the requirements. Pair programming was not done successfully, this was because some members of the team preferred to work at home or alone in the lab, and then there were personality clashes between other members.

Two members of this team, G1 and G2 worked tirelessly throughout the project and made great efforts to ensure that everyone felt like they were part of the team. G2 in particular exhibited excellent team leadership skills and proved to an outstanding member of the team in terms of output, technical ability and how he held the team together.

"I think special credit must go to G2. Not only for his tireless efforts butfor the way he has held the team together." G1 
"Gl has been an enthusiastic and hard working member of our team. Gl has helped to develop several ideas and has shown a lot of commitment." G2

Another member of the team G6 worked hard but unlike G1 and G2 could not maintain genial relations with the other members. A serious problem was the complete breakdown of the relationship between G6 and G3. G6 was angered by what he perceived as apathy and lack of initiative from G3, G4, and G5. G6 tried to increase their involvement by shouting at the other members; this only served to isolate G3. G3's apathy and subsequent detachment caused problems due to a lack of communication with other members about work done. It also required a lot of effort and patience from G2 to bring G3 back into the fold. This affected the performance of the software, as key parts of the project assigned to G3 were left undone and other members had to sacrifice existing tasks to take up G3's.

"I find this project to be very boring. Genesys is boring, I am not happy with how things are going. I have no real interest in this project." G3

"G3's apathy is worrying." G2

Having meetings with and listening to ideas from the client was another source ofturmoil. Some members, particularly G6, accused the client of lying and expressed doubts about his morality and honesty. G6 was successful in creating an atmosphere of mistrust and paranoia with regards to the client by questioning his sanity and integrity. G6 felt the client was lying about servers and different technologies the team could use. This caused other members to question the clients' integrity. Some members, particularly G1, felt that the client was making statements based on ignorance but G6 argued that he was deliberately lying. G6 showed anger and impatience when asking questions. A major problem surfaced when the client said he was willing to give up the system, this threw the teams plans into chaos for a short period. Another cause for concern was the differing opinions bet ween the team and the client with regards to third party soft ware which could be used to aid them. The client claimed that third party software was freely available but refused to give any pointers; this caused the team to question whether he was being serious. G6 accused the client of lying about this. The end result was that the system worked but a key requirement was missing. A lot oftime was lost as the team concentrated on this issue and neglected more pressing issues to satisfy the client.

Two incidents served to pour fuel on an already raging fire in terms of team-client relations. The first incident was an alleged confidentiality breach. The client accused a team member of sending details of his idea to someone out side of Genesys. All team members rigorously denied these allegations and were subsequently accused of lying. The second incident was a threat from the client to walk out of the project. Half-way through the client said he was on the brink of calling it a day.

This distrust and anger between client and team went both ways had a negative impact on the product. The team did not trust the client enough to let him modify any part of the structure of the DB. The client wanted additional DB queries; G2 commented that it would become unwieldy if this was the case. G1 also noted that the clients' requests were too complex for the existing DB and they would bring in too many new parameters. The client wanted a quick system. G2 said they will have to trade off quality for time and cost. A lot of cat egories of the DB were changed; this meant work was presented that didn't have the full functionality. The client grew impatient as the team struggled to keep pace with the changing requirements. Minor bugs were uncovered towards the end of the project.

This team achieved ambiguous success. Perhaps their greatest achievement was to complete the project and produce a functional piece of soft ware (albeit with specified functionality missing). At times it seemed as if the team would implode and the problem with the client proved to be 
damaging throughout. Two members of the team performed admirably throughout in terms of their technical ability and in how they managed otherteam members. This was noted by the managers, and the two in question were rewarded with high individual marks. The whole team mark suffered as there wasn't an equal distribution of work and conflicts between certain members made it difficult for them to work together. The client expressed dissatisfaction several times throughout the project. The alleged confidentiality breach and threat to walk out stand out as points wherethe relationship between the team and client was at an all time low. During other periods of the project there was low level hostility and distrust. As a result of this, on completion the client accepted that some of the important functionality had been implemented. However, he also remarked that more work needed to be done and the final system was barely usable.

Table 10: Se ve rity and Impact of Conflict in Genesys Team 4

\begin{tabular}{|l|l|l|l|}
\hline Conflict Type & Se ve rity & Positive Impact & Negative Im pact \\
\hline Task & High & $\begin{array}{l}\text { Helped to int egrate } \\
\text { members from diverse } \\
\text { backgrounds }\end{array}$ & $\begin{array}{l}\text { Frequently became too angry and } \\
\text { not only between team members } \\
\text { also with the client }\end{array}$ \\
\hline Process & Moderate & $\begin{array}{l}\text { Forced certain mem- } \\
\text { bers to come to the } \\
\text { fore }\end{array}$ & $\begin{array}{l}\text { The fact that people felt they } \\
\text { were being forced led to ill feel- } \\
\text { ing }\end{array}$ \\
\hline Relationship & Moderate & N/A & $\begin{array}{l}\text { Led to the alienation of one } \\
\text { member and reduced roles for } \\
\text { two others. } \\
\text { Caused a breakdown in the rela- } \\
\text { tionship with the client. }\end{array}$ \\
\hline
\end{tabular}

\section{Answers to Research Questions}

This section contains a series of charts with the intention of creating a broad picture of the conflict that took place within SE teams working on Observatory projects. Additionally it provides answers to the research questions. Figure 8 shows the overall \% of constructive and destructive conflicts in the observed projects.

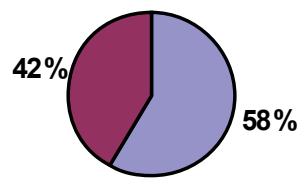

$\square$ Con structive
$\square$ De structive

Figu re 8. O ve rall \% of Constru ctive and Destructive Conflict for all Teams

Figure 8 shows that there was a majority of constructive conflicts, $58 \%$ as against $42 \%$ of destructive conflicts. This is closerthan expected at the start of the project as the initial expectation was that there would be lower levels of destructive conflict. As regards the research question "are some forms of conflict more destructive than others in an SE team environment" from Figure 9 
we can see that the majority of conflicts which took place in all of the projects were of the task type. A clear majority of task conflicts were constructive. Although it must be added that the amount of destructive task conflict was by no means insignificant.
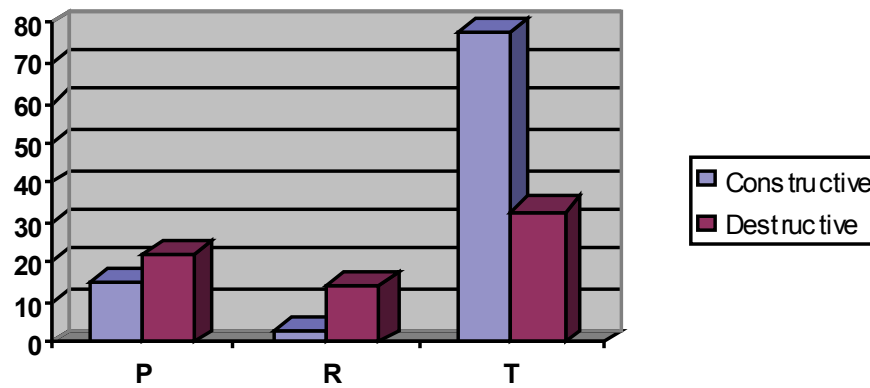

$\square$ Destruc tive

\section{Figu re 9. Con structive and Destructive Conflict Types}

This was not the case for process or relationship conflicts in which the majorities were destructive. The conflicts were overwhelmingly destructive in the case of relationship conflict, as Figure 10 illustrates:

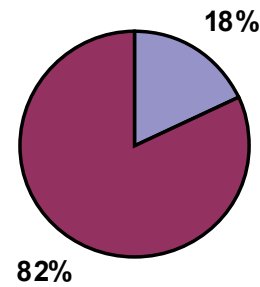

$\square$ Constructive

$\square$ De structive

Figure 10. Constructive and Destructive Relation ship Con flict

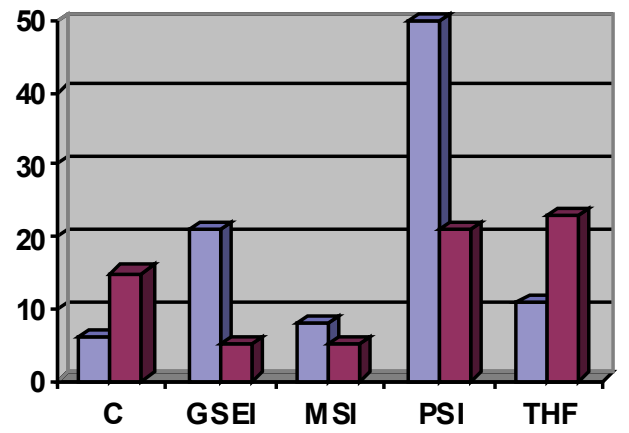

$\square$ Constructive

$\square$ Destructive

Figu re 11. Constructive and Destructive Conflict by Issue Type

As for the second research question, "Are certain issues more likely to lead to constructive or destructive conflict?" from Figure 11 one can see that PSI and GSEI were the issues most likely to result in constructive conflict and $\mathrm{THF}$ and $\mathrm{C}$ were most likely to result in destruct ive conflict. 
The PSI and GSEI disc ussed were project or technical issues and involved discussing details of the project as well as technical factors, such as design methodologies, systems analysis, and programming languages. In contrast THF issues related more to the personalities and individual idiosyncrasies of team members. If a conflict broke out during a THF discussion there was a greater chance of it becoming destructive due to the personal nature of the issue.

As discussed earlier several teams had problems with their respect ive clients. This helps to explain why there was a higher number of destructive as opposed to constructive client issues. Due to these problems, issues in which the client was disc ussed were at great risk of turning into destructive conflicts.

There is a specific focus on client and THF issues as they were most likely to end in a destructive conflict taking place. In terms of THF, relationship and process conflicts were the most problematic, whereas for client it was process and task. Only one client issue ended as a relationship conflict, and this was the damaging confidentiality breach which took place in Genesys Team 4. This is understandable as there is less chance of a relationship conflict breaking out between a member of an SE team and the project client than there is of one breaking out between members of teams. There is unlikely to be the same amount of time spent together and less discussion on non-project related topics. Thetopic of discussion can change when members of a team are discussing with each other, and personal dislikes are more likely to come to the fore due to increased contact. Table 11 shows destructive conflict types and issues discussed as well as listing some of the main causes which were observed in multipleteams.

Table 11. Destructive Client Conflicts an d Causes

\begin{tabular}{|c|c|c|c|}
\hline & \multicolumn{3}{|c|}{ Issue } \\
\hline Conflict Type & Client & THF & PSI \\
\hline Process & $\begin{array}{l}\text { Contacting clients; } \\
\text { Arranging meetings; } \\
\text { Multiple Clients. }\end{array}$ & $\begin{array}{c}\text { Time keeping; } \\
\text { T ime of meetings; } \\
\text { Working practices; } \\
\text { Planning for work } \\
\text { during holidays; } \\
\text { Allocating tasks. }\end{array}$ & $\begin{array}{c}\text { Budgets/Stage plans; } \\
\text { Standards; } \\
\text { Timesheets; } \\
\text { Arranging visits. }\end{array}$ \\
\hline Relationship & $\begin{array}{l}\text { Confidentiality } \\
\text { breach. }\end{array}$ & $\begin{array}{c}\text { Political issues; } \\
\text { Apathy; } \\
\text { Personality clashes; } \\
\text { Pedantry; } \\
\text { Sarcasm. }\end{array}$ & $\mathrm{N} / \mathrm{A}$ \\
\hline Task & $\begin{array}{l}\text { Understanding re- } \\
\text { quirements; } \\
\text { Documenting re- } \\
\text { quirements; } \\
\text { Demonstrating soft- } \\
\text { ware. }\end{array}$ & $\begin{array}{l}\text { Recording Informa- } \\
\text { tion }\end{array}$ & $\begin{array}{c}\text { Design documents; } \\
\text { Feasibility reports; } \\
\text { Data modeling; } \\
\text { Function point analysis. }\end{array}$ \\
\hline
\end{tabular}




\section{Discussion}

The aim of this study was to analyze different types of conflict in a team based SE environment and to attempt to uncover the extent to which conflicts where either constructive or destructive. This classification was done via referring to field notes based on observations of SE teams working on projects for industrial clients.

A key finding was that some types of conflict were beneficial particularly those which were PSI or GSEI and of atask type. Previous research in non-SE contexts has found that moderate amounts of task conflict can be beneficial. Task conflict can influence the affective acceptance of team decisions and prevent the emergence of group-think (Janis, 1972; Turner \& Pratkanis, 1994). Although on the whole the findings relating to task conflict were beneficial, there was a large minority of destructive task conflicts. This shows that in an SE environment, task conflict need not always be constructive and can indeed result in destructive conflict. Several factors were found to influencethis, including the methodology being adhered to, the nature of the project, the relationship with the project client, demographic diversity, and differing levels of skill and experience.

Some of the experienced members proved to be helpful to their team mates, e.g. G1 and G2 from Genesys T eam 4 . They showed patience when asked questions and were willing to spend time teaching techniques to less experienced members. Others, e.g. G6 from Genesys Team 4 and B3 from Software Hut team B, lacked such patience. They didn't share their knowledge in an effective manner, nor did they establish any kind of rapport with other members of the team. There was a third type such as D1 from Maxi Team B and E2 from MaxiTeam C who were both experienced and hadhigh skill levels in certain programming languages. These members tended to work alone. Whilst they didn't engage in conflict with less experienced members, they also made no real efforts to involve them in the work. Their preference was to remain aloof, and as a result there was little conflict between them and their team mates.

Although neglected in comparison with task and relationship conflict, the previous research has shown that process conflict has a negative impact on both performance and in terms of damaging the relationship between team members. When there was intense argument about task assignment, the actual completion of the task took longer. Constantly debating who was going to do what and when they were going to do it led to uncertainty. The findings reported in this paper confirm these earlier studies as more destructivethan constructive process conflicts were observed during the course of this research.

With regards to relationship conflict the results from this study confirm the findings of earlier studies in different contexts. Over $80 \%$ of observed relationship conflicts in a SE context resulted in destructive conflict. The damaging effect of relationship conflict becomes clearer when one looks at the results gathered during this study relating to THF and Client issues. Discussion of THF issues led to disagreements about values, personal norms, personal taste, and inter-personal disputes which eventually spilled over into insults and personal attacks. Similarly, certain client issues were of a personal nat ure and proved to be disruptive to the workings of the team in question. This contrasts with the findings concerned with PSI and GSEI issues. Discussions limited to core project or technical issues were less likely to end in a destructive conflict. Discussing these issues was beneficial for teams as it enhanced performancethrough a synthesis of diverse perspectives and led to an increase in understanding.

The results support the idea that conflict per se is not always negative. In some of the observed projects, teams which had more conflict episodes outperformed those who experienced less conflict. One of the teams dogged by high levels of conflict throughout still managed to produce a high quality system on completion of the project. What this paper and other studies highlight is that conflict need not be a debilitating factor in team based projects. Some conflict was found to 
be beneficial as was explained above. In other cases, high levels of technical skill and determination from individual team members proved to be the catalyst for gett ing teams over the finishing line.

In terms of project outcomes it was not the teams who were dogged by frequent relationship or process conflict who suffered most.T eams in which most of the work was done by one member did not suffer from frequent process or relationship conflicts. This was the case for two of the Maxi teams B and C. In terms of project outcomes team B did not finish either the documentation or the software, and team $\mathrm{C}$ managed to complete a sub-standard system and incomplete documentation at the last minute. This was an interesting finding as it suggests that over-reliance on one member and communication barriers are potentially more damaging to project outcomes than frequent episodes of destructive conflict. Genesys Team 4 and Software Hut Team B experienced many destructive conflicts yet never fell into the trap of relying on one member to do most of the work or allowed one person to dominate the thinking of the team. Both teams had members who reacted in a negative manner to the conflict but the main protagonists still managed to work together towards a common goal.

\section{Limitations}

There are a number of limitations that need to be considered when discussing the results that were obtained. The subjects were students, not professional practitioners, although some of them did have experience in SE. Therefore further work is needed to confirm these results in an industrial setting.

Secondly, it was not possible to monitor all communications and meet ings. It was possible to observe meetings which took place on the university campus and a selection of periods when teams were working in university computer rooms. However, meetings also took place off campus, in the home of a particular student, in pubs, or in coffee houses. It was possible to attend some of the meetings which took place in coffee houses. The students tended to be more relaxed as these meetings were not taking place on campus and there was more of a social atmosphere. However some of these meet ings took place either during the evening or on weekends and it was not possible to attend.

Additionally other forms of communication were utilized by the students. The researchers were able to see a number of e-mails sent between team members, managers, and clients, but most of the private e-mails sent between members of the team were not viewed. The students made use of instant messaging software such as MSN messenger especially during holiday periods. Researchers did not observe any of these conversations or listen to any phone conversations between team members.

Another limitation is that the sample size is relatively small. This constitutes a threat to the external reliability of the study. There is also the issue of reactivity. Reactivity is the negative or unintended effect on research subjects of being investigated. Two classic instances of reactivity are the Hawthorne and social desirability effects. Did the presence of the researcher have any affect on the behavior of the research subjects, did the fact that they were being observed contribute significantly to the results? Did the fact that they were being observed and interviewed make them behave in a manner which would be viewed favorably by the researchers? It cannot be said with $100 \%$ certainty that being observed did not have any effect on the students' behavior. But the fact that there were instances of disruptions, admissions that work had not been done, and anger towards the clients and other team members suggests that the presence of researchers did not have a significant effect on student behavior. 
Finally, several teams were ethnically and culturally diverse. How cultural differences may impact levels of conflict in SE teams was not addressed during this present study. This issue is worthy of further study and should be addressed in more detail.

\section{Conclusions and Future Work}

The results from this study build on previous work which has uncovered different types of conflict in SE teams and stated whether or not said conflict was constructive or destructive (Elam \& Walz, 1988; Sawyer, 2001). Conflict can have both a positive and negative effect on the progress of and the interactions between members of SE teams. As expected from previous results, task conflict was the most common type encountered during the duration of this project. Task conflict was most beneficial when based on core project or technical issues. Process conflict was in total slightly more destructive. As was anticipated relationship conflict, which is related more too personal likes and dislikes, was overwhelmingly destructive.

Several teams experienced problems with clients, methodologies, and personality/cultural clashes between team members. Hostility toward the project client or the methodology tended to result in destructive conflicts taking place whenever these issues were discussed in selected teams. Similarly personal antagonism between team members had the effect of disrupting project or technical issues. Members started to engage in one-upmanship and tried to find holes in other people's arguments as opposed to contributing constructive criticism.

Based on this research several fut ure research directions can be realistically pursued. Firstly, one could look at the mechanisms for resolving conflict in SE teams. Secondly, there is the issue of one form of conflict mutating into another, e.g. what starts as a task conflict could result in a relationship conflict due to the interactions that take place. This is an issue worthy of further investigation as it may help to identify how and why mutations occur and if there are any patterns that result in a constructive task conflict mutating into a destructive relationship conflict. Thirdly, this research has uncovered problems in the relationship between SE teams and clients. Further work is needed to look specifically at the relationship between teams and clients with emphasis being put on the conflict episodes. This will help to uncover whether some forms of conflict can actually strengthen the relationship between the team and the client. Finally, one could compare levels and types of conflict in teams following different SE methodologies.

This work has contributed to the growing body of literature dealing with human factors of SE. There are several implications for SE; awareness that conflict can serve both a positive and a negative role in team working can help to create understanding and eventually lead to more harmonious team working.

Many people in different subjects have stated that differences between people can either help a team to grow and be strong or they can help to destroy it from within. What is lacking in such statements in an SE context is an explanation of how and why this is the case. By analyzing conflict in SE teams and measuring whether the effects are constructive or destructive. This study has gone some way towards explaining how different viewpoints and an open exchange of ideas can be a catalyst for a successful project outcome.

\section{References}

Amason, A. C. (1996). Distinguishing the effect of functional and dysfunctional conflict on strategic decision making: resolving a paradox for top managem ent teams. Academy of Management Journal, 39, 235-245.

Amason, A. C., \& Sapienza, H. (1997). The effects of top managem ent team size and interaction norms on cognitive and affective conflict. Journal of Management, 23(495-516). 
Atkinson, P. (1990). The ethnographic imagination: Textual constructions of reality. London: Routledge.

Baxter, L. A. (1982). Conflict management: An episodic approach. Small Group Behavior, 13(1), 23-42.

Beck, K. (1999). Embracing change with extreme programming. IEEE Computer, 32(10), 70-77.

Beck, K. (2000). Extreme programming explained: Embrace change. Reading, Mass: Addison Wesley, Longman.

Becker, H. (1993). Problem of inference and proof in participant observation (Reprint ed.). Irvington.

Cohen, G. S., \& Bailey, E. D. (1997). What makes teams work: Group effectiveness research from the shop floor to the executive suite. Journal of Management, 23(3), 239-290.

Curtis, B. (1991). Techies as non-technological factors in software engineering. Proceedings of the 13th International Conference on Software Engineering (ICSE 1991), 147-148.

Curtis, B., Kellner, M. I., De Marco, T., Kishida, K., Schlumberger, M., \& Tully, C. (1991). Nontechnological issues in software engin eering. Proceedings of the 13th International Conference on Software Engineering (ICSE 1991).

Curtis, B., Krasner, H., \& Iscoe, N. (1988). A field study of the software design process for large systems. Communications of the ACM, 31(11), 227-245.

Curtis, B., Walz, D., \& Elam, J. (1993). The dual role of conflict in group software requirem ents and design activities. Communications of the ACM, 36(10), 63-76.

Darling, J. R., \& Walker, W. E. (2001). Effective con flict manag ement: Use of the beh avioural style model. Leadership \& Organization Development Journal, 22(5), 230-242.

De Dreu, C. K. W. (1997). Productive conflict: The importance of conflict management and con flict issues. In C. K. W. De Dreu \& E. Van de Vliert (Eds.), Using conflict in organizations (pp. 9-23). London: Sage.

De Dreu, C. K. W., van Dierendonck, D., \& De Best-Waldhober, M. (2005). Conflict at work and individual well-being. In M. J. Schabracq, J. A. M. Winnubst \& C. L. Cooper (Eds.), The handbook of work and health psychology (2nd ed., pp. 495-515): John Wiley \& Sons.

De Dreu, C. K. W., \& van Vianen, A. E. M. (2001). Managing relationship conflict and the effectiven ess of organizational teams. Journal of Organizational Behavior, 22, 309-328.

De Dreu, C. K. W., \& Weingart, L. R. (2003). Task versus relationship conflict, team performance and team member satisfaction: A meta-analysis. Journal of Applied Psychology, 88(4), 741-749.

Desivilya, H. S. (1998). Using conflict in organizations. International Journal of Conflict Management, 9(9), 369-376.

Deutsch, M. (1980). Over 40 years of conflict research. In L. Festinger (Ed.), Over fifty years of conflict research (pp. 46-77). New York: Oxford University Press.

Dijkstra, M. T., van Dierendonck, D., \& Evers, A. (2005). Responding to conflict at work and individual well-being: The mediating role of flight behaviour and feelings of helplessness. European Journal of Work and Organizational Psychology, 14(2), 119-135.

Dyson, J. W., Godwin, P. H., \& Hazlewood, L. A. (1976). Group composition, leadership orientation, and decisional outcomes. Small Group Behavior, 7(1), 114-128.

Elam, J. J., \& Walz, D. W. (1988). A study of conflict in group design activities: Implications for computer supported cooperative environments. Proceedings of the 21st Annual Hawaii International Conference on Decision Support and Knowledge Based Systems Track, 247-254.

Giebels, E., \& Janssen, O. (2005). Conflict stress and reduced well-being at work: The buffering effect of third-party help. European Journal of Work and Organizational Psychology, 14(2), 137-155.

Giebels, E., Janssen, O., Van de Vliert, E., \& Nauta, A. (1999). Constructive conflict at work. Journal of Organizational Behavior, 20, 475-491. 
Guetzkow, H., \& Gyr, J. (1954). An analysis of conflict in decision-making groups. Human Relations, 7, 367-381.

Jackson, K. M., Johnson, S. C., Peterson, R. S., \& Trochim, W. M. K. (2002). A multi-faceted appro ach to process conflict. Proceedings of the 15th Annual Conference of the International Association for Conflict Management, Salt Lake City, Utah.

Janis, I. L. (1972). Victims of group-think: A psychological study of foreign policy decisions and fiascoes. Boston, MA: Houghton Mifflin.

Jehn, K. A. (1992). The impact of intragroup conflict on effectiveness: A multi-method examination of the benefits and detriments of conflict. Unpublished PhD Thesis, Northwestern University, Graduate School of Managem ent, Evanston, IL, USA.

Jehn, K. A. (1995). A multimethod examination of the benefits and detriments of intrag roup con flict. Administrative Science Quarterly, 40, 256-282.

Jehn, K. A. (1997). A qualitative analysis of conflict types and dimensions in organizational groups. $A d-$ ministrative Science Quarterly, 42, 530-557.

Jehn, K. A., \& Chatman, J. A. (2000). The influence of proportional and perceptual conflict composition on team perform ance. International Journal of Conflict Management, 11(4), 741-763.

Jehn, K. A., \& Mannix, E. (2001). The dynamic nature of con flict: A longitudinal study of intragroup conflict and group performance. Academy of Management Journal, 44, 238-251.

Jehn, K. A., Northcraft, G., \& Neale, M. A. (1999). Why difference makes a difference: A field study of diversity, conflict, and performance in work groups. Administrative Science Quarterly, 44, 741-763.

Jehn, K. A., \& Shah, P. (1997). Interpersonal relationships and task performance: An examination of mediating processes in friendship and acquaintance groups. Journal of Personality and Social Psychology, $72,775-790$.

Johnson, D. W. (1998). Maximizing instruction through cooperative learning. Prism, 7(7), 24-29.

Lofl and, J., \& Lofland, L. (1984). Analysing social settings: A guide to qualitative observation and analysis. Belmont, CA: Wadsworth.

Mead, M. (1975). Growing up in New Guinea: A study of adolescence and sex in primitive societies. Harmondsworth: Penguin.

Neilsen, F. (1996). Human behavior: Another dimension of standards setting. Standard View, 4(1), 36-41.

Passos, A. M., \& Caetano, A. (2005). Exploring the effects of intragroup conflict and past performance feedback on team effectiveness. Journal of Managerial Psychology, 20, 231-244.

Pelled, L. H., \& Adler, P. S. (1994). Antecedents of intergroup con flict in multifunctional product development teams: A conceptual model. IEEE Transactions on Engineering Management, 41(1), 21-28.

Pfleeger, S. L. (2001). Software engineering: Theory and practice (2nd ed.): Prentice-Hall.

Pinkley, R. L. (1990). Dimensions of conflict frame: Disputant interpretations of conflict. Journal of Applied Psychology, 75, 117-126.

Pressman, R. S. (2001). Software engineering: A practitioner's approach (5th ed.): McGraw Hill.

Rognes, J. (1998). Are cooperative goals necessary for constructive con flict processes? Applied Psychology, 3(3), 331-336.

Sawyer, S. (2001). Effects of intra-group conflict on packaged soffw are development team performance. Information Systems Journal, 11(2), 155-178.

Schweiger, D., \& Sandberg, W. (1989). The utlization of individual capabilities in group approach es to strategic decision making. Strategic Management Journal, 10, 31-43. 
Simons, A. J. H. (1999). The discovery method for object-oriented software engineering. Retrieved from http://www.dcs. shefac.uk/ ajhs/discovery/

Sommerville, I. (2004). Software engineering (7th ed.): Addison Wesley.

Tjosvold, D. (1997). Conflict within interdependence: Its value for productivity and individuality. In C. K. W. De Dreu \& E. Van de Vliert (Eds.), Using conflict in organizations (pp. 23-37). Thousand Oaks: Sage.

Tjosvold, D., Hui, C., \& Law, K. S. (2001). Constructive conflict in China: Cooperative conflict as a bridge between East and West. Journal of World Business, 36(2), 166-183.

Turner, M. E., \& Pratkanis, A. (1994). Social identity maintenance pres criptions for preventing groupthink: Reducing identity protection and enhancing intellectual conflict. International Journal of Conflict Management, 5, 211-222.

Van de Vliert, E., \& De Drue, C. K. W. (1994). Optimizing performance by conflict stimulation. International Journal of Conflict Management, 5, 211-222.

Wall, V., \& Nolan, L. (1986). Perceptions of inequity, satisfaction, and conflict in task-oriented groups. Human Relations, 39(1033-1052).

West, M. A., \& Anderson, N. R. (1996). Innovation in top management teams. Journal of Applied Psychology, 81, 680-693.

Wilmot, W. W., \& Hocker, J. L. (2001). Interpersonal conflict: McGraw Hill Higher Education.

\section{Biography}

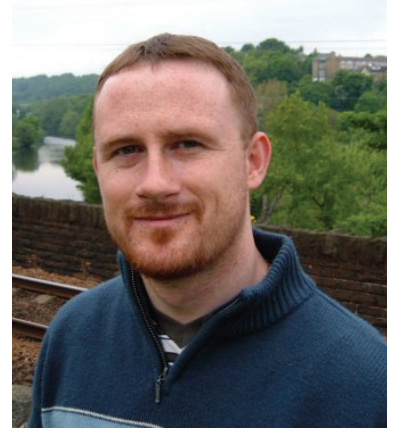

John Karn is a post-doctoral researcher in the Department of Computer Science at the University of Sheffield, UK. His research interests include the effect of conflict on the performance of teams, conflict resolution strategies, the interaction of personalities in teams, and the relationship between project teams and the client who has commissioned the software. He completed his undergraduate studies in 2001 at the University of Hull. He then received MPhil and PhD degrees from the University of Sheffield and was awarded his PhD in 2006. 